\title{
OUTER SPACE WITHOUT ARMS: SUBSTRATUM OF A PEACEFUL REGIME FOR COMMON BENEFIT
}

\author{
Subrata Roy Chowdhury*
}

\section{DISCORDANT TRENDS IN DISARMAMENT PROGRAMMES}

One can observe two conflicting trends in the disarmament programme having special relevance to the problem of prevention of an arms race into outer space. The teleological linkage between reduction of strategic offensive weapons and limitation of defensive weapons as reflected, for instance, in the two pre-ambular paragraphs of the Anti-Ballistic Missile Treaty (ABM) of 1972 has been well demonstrated in recent years. The series of sophisticated arms control accords, coinciding in particular with the gradual decline and eventual demise of world communism, have played a significant role in the reorientation of the national security-international peace syndrome.

Apart from the 13 multilateral disarmament agreements in force today, ${ }^{1}$ the progressive trend in bilateral initiative commenced with the historic break-

\footnotetext{
* Of Lincoln's Inn, Barrister; Senior Advocate, Supreme Court of India; Member, International Institute of Space Law; International Space Law Committee, International Law Association. The Editors were greatly saddened to hear that Subrata Roy Chowdhury passed away on 29 October 1994.

${ }^{1}$ Geneva Protocol for the Prohibition of the Use in War of Asphyxiating, Poisonous or Other Gases, and of Bacteriological Methods of Warfare (1925); The Antarctic Treaty (1959); Treaty Banning Nuclear Weapon Tests in the Atmosphere, in Outer Space and under Water (1963); Treaty on Principles Governing the Activities of States in the Exploration and Use of Outer Space, including the Moon and Other Celestial Bodies (1967); Treaty for the Prohibition of Nuclear Weapons in Latin America (1967); Treaty on the Non-Proliferation of Nuclear Weapons (1968); Treaty on the Prohibition of the Emplacement of Nuclear Weapons and Other Weapons of Mass Destruction on the Seabed and the Ocean Floor and in the Subsoil thereof; Convention on the Prohibition of the Development, Production and Stockpiling of Bacteriological (Biological) and Toxin Weapons and on Their Destruction (1972); Convention on the Prohibition of Military or Any Other Hostile Use of Environmental Modification Techniques (1977); Agreement Governing the Activities of States on the Moon and Other Celestial Bodies (1979); Convention on Prohibitions or Restrictions on the Use of Certain Conventional Weapons Which May Be Deemed to Be Excessively Injurious or to Have Indiscriminate Effects (1981); South Pacific Nuclear Free Zone Treaty (1985); Treaty on Conventional Armed Forces in Europe (1990).
}

Asian Yearbook of International Law, Volume 4 (Ko Swan Sik et al., eds.; 90-411-0872-6 ${ }^{\circledR} 1995$ Kluwer Law International; printed in Great Britain), pp. 3-24 
through at the conclusion of the Intermediate Range Nuclear Forces (INF) Treaty signed in Washington on December 8,1987 . Hailed by $L e M^{\prime}{ }^{2}{ }^{2} e^{2}$ as 'the dawn of the new philosophy' and by President REAGAN as a 'landmark in post-war history', the three outstanding features of the INF Treaty ${ }^{3}$ are: first, mandatory injunction for the elimination of an entire class of missiles (intermediate and short range) with a range between 500-5000 kilometres; second, prohibitory injunction against future production and flight-testing of such weapons; and last but not the least, the provision for unprecedented onsite verification measures.

The next important events in the bilateral arms control scenario are the consensus on the Strategic Arms Control Treaty (START-I) of 31 July 1991 and START-II of 3 January 1993. As explained by President BUSH in his transmittal letter of 15 January 1993 to the Senate, the START-I Treaty was the first treaty actually to reduce strategic offensive arms of both countries with overall reductions of 30-40 per cent and reduction up to 50 per cent in the most threatening systems. Building upon it, the START-II treaty surpassed the accomplishment by further reducing strategic offensive arms for promoting the stability of the strategic nuclear balance. It bans deployment of the most destabilising type of nuclear weapon systems, namely, land-based intercontinental ballistic missiles (ICBMs) with multiple independently targetable nuclear warheads. The central limits of START-II require reductions to 3000-3500 warheads by January 1, 2003 which may be reached earlier, by 2000, if both sides can agree on a programme of assistance to the Russian Federation regarding dismantling strategic offensive arms within a year after entry into force of the treaty. There are sub-limits to the aforesaid central limits. ${ }^{4}$

President BUSH declared that the acceptance of the reductions served as a "clear indication of the ending of the Cold War", while President BORIS YELTSIN exclaimed that the START-II treaty was a "treaty of hope" and that "we will be able to hand over to our children, the children of the 21st century, a more secure world". ${ }^{5}$ Indeed, YELTSIN explained that the treaty "strengthens the security of Russia rather than weakens it", inter alia, because the proposed reductions would cost Russia "much less than the mere maintenance of nuclear

\footnotetext{
${ }^{2}$ Reproduced in The Guardian Weekly, 20 December 1987 at 13.

${ }^{3}$ Text of the INF Treaty (Treaty on the Elimination of Intermediate-Range and Shorter Range Missiles) in: 27 ILM (1988) 90-98.

${ }^{4}$ MARIan NaSH (LeICH), 'Contemporary Practice of the United States Relating to International Law', 87 AJIL (1993) 258-281 at 258-259.

${ }^{5}$ Ibid. at 259; 4 US Department of State Dispatch No. 2 (January 11, 1993) 20.
} 
weapons systems in a safe condition" and again, Russia saves seriously on the two most expensive items of expenditure, namely, verification and inspection. ${ }^{6}$

The euphoria thus emanated was considerably subdued by a divergent trend aimed at promoting an arms race particularly in the area of conventional arms. The genesis of this trend can be traced to the lessons learnt from the recent Gulf war popularly described as Desert Storm. The first lesson is that it has shown how devastating air weapons can be in any future warfare. If the high ground of air superiority is important today, then the high ground of space superiority may be crucial tomorrow. The second lesson is the importance of advanced conventional weapons in any future warfare. A defined strategic objective could be achieved by air power alone capable of delivering advanced conventional munitions. In other words, the exercise for nuclear disarmament is to be counterbalanced by a parallel exercise for refined conventional munitions rearmament. Both the United States and the erstwhile Soviet Union or CIS or Russia are contemplating identical strategies.

In a recent report (1989) Admiral CROWE and General POWELL of the US stated:

"Space is the ultimate 'high ground' for military operations of the future [. . . ] it is very possible that the near future will include space-based weapons."

The idea was further expanded by Maj. Gen. DoN MILLER (United States Marine Corps) who commented that space weapons "may well provide support to a wide range of future military missions" ${ }^{8}$ According to Miller, the advantage lies in forward presence, rapid response, adaptive capability and flexibility. He noted the ability to deliver conventional ordnance from space could be the ultimate in strategic bombing without risking any American lives. It could cover any area of the world, 24 hours a day, and be able to deliver firepower within minutes or a few hours. Any weapon system of this kind has the great advantage of compressing time and space. ${ }^{9}$

This new development was perceived as a serious threat by the Soviet Union/CIS/Russia to their own security because the advanced weaponry would

\footnotetext{
${ }^{6}$ Ibid.

${ }^{7}$ Letter from General Powell to Secretary CHENEY, 'Report on Roles and Functions of Armed Forces', dated 1989, written by Admiral CROWE at the end of his term as Chairman and forwarded by General Powell at the beginning of his term. Also see, HAL E. HAGEMEIER, 'A Recommended National Security Strategy for a Certain Class of Space Weapons or What do We Do About Bombs in Space?', 11 Comparative Strategy (1992) 49-64 at 52.

${ }^{8}$ Speech given by Maj. Gen. Don MiLler, United States Marine Corps, at the Armed Forces Communications and Electronic Association, Annual Meeting, 24 May 1990.

${ }^{9}$ HAGEMEIER, loc.cit. n. 7 at 52 and 61 (note 16).
} 
likely be incorporated into NATO force posture. The most important lesson of Desert Storm relates to the nature of future warfare. Gen. Maj. SLIPCHENKO was of the view that the primary contingency for military planning would be the 'aerospace war' in which the adversary would employ deadly weapons with the object of destroying certain military targets. Such weapon systems would include ballistic missiles with manoeuvring warheads, orbital airplanes, cruise missiles with ranges up to 4000-5000 kilometres and the widespread application of stealth technology. SLIPCHENKO concluded:

"In order to support the 'air war', wide use can be made of space-based systems for reconnaissance and attack, communications and meteorological services. There are prospects for systems for the destruction of land-based targets from space." 10

Apart from earth-to-space and space-to-space weapons, the development of non-nuclear space-to-earth weapon systems has been suggested in certain quarters. The technology for such a system is yet to be developed but it is stated to be within the capability of the USA, Russia and other space-faring nations. HAL E. HAGEMEIER for instance, has suggested the experiment despite being aware of popular reaction against it and despite the danger that it might fuel anti-ballistic programmes of other space-faring nations. HAGEMEIER contends that there is no international law in general or space-related treaty in particular which prohibit the development of such a weapon system for selfdefence or national security. ${ }^{11}$

\section{PEACEFUL USE OF OUTER SPACE}

This brings us to the central theme of international space law that exploration and use of outer space for peaceful purposes should be done in the common interest of all mankind and for the benefit of all peoples. This is a fundamental obligation and prevention of an arms race in outer space is a condition precedent to its fulfilment.

There are two basic documents of the United Nations which reflected this principle long before the conclusion of the Treaty on Principles Governing the

\footnotetext{
${ }^{10}$ Gen. Maj. V.I. SLIPCHENKo, 'Impending Changes as a Result of Reform in Plans for the Use of Soviet Armed Forces', National Defence University, 15 (March 20, 1991) at 3-5. Also see Linda Hor Vlahos, Michael J. Deane and MarC J. Berkowitz, 'Aerospace Defence Requirements in Post-Soviet Russia', 11 Comparative Strategy (1992) 431-445 at 436-437.

"See, generally, HAGEMEIER, loc.cit. n. 7.
} 
Activities of States in the Exploration and Use of Outer Space, Including the Moon and Other Celestial Bodies of 27 January 1967 (hereafter, the 1967 treaty). General Assembly Resolution No. 1721 (XVI) of 20 December 1961 recognizes the "common interest of all mankind in the progress of the exploration and use of outer space for peaceful purposes" while resolution no. 1962 (xvii) of 13 December 1963 laid down that the activities of States in this area shall be carried out "in accordance with international law, including the Charter of the United Nations, in the interest of maintaining international peace and security and promoting international cooperation and understanding". ${ }^{12}$ As the late Judge MANFRED LACHS, one of the principal architects of international space law, observed:

"The reason for this seems self-evident. Not only does the Charter constitute an integral part of contemporary international law, but in the light of its provisions it is something in the nature of a 'higher law', a Magna Carta of international relations in the world of to-day. The growth of the organization has given it an almost universal character." ${ }^{13}$

Two of the conclusions of Judge LACHS are:

(1) The application of international law, including the Charter of the United Nations, to outer space results from the opening up of this new sphere to human activities;

(2) This implies automatic extension to outer space of the principles and rules of international law, of the Charter of the United Nations - mutatis mutandis - wherever this may be necessary. ${ }^{14}$

The expression 'peaceful purposes' in outer space in General Assembly resolution 1721 (XVI) of 1961 or the term 'peaceful use' from its very inception became the subject of two conflicting interpretations. First, the term would exclude only aggression but not military use; second, it would mean non-military purposes of a peaceful nature. In support of the first interpretation, then Senator GORE, for instance, said as early as on 3 December 1962:

"It is the view of the United States that outer space should be used only for peaceful purposes that is, non-aggressive and beneficial purposes." 15

\footnotetext{
${ }^{12}$ Texts in Yearbook of the United Nations 1961 at 35-36 and id. 1963 at 101-102.

${ }^{13}$ MANFREd LACHS, 'The International Law of Outer Space', 113 Recueil des Cours (1964-III) 42.

${ }^{14}$ Ibid. 45.

${ }^{15}$ UN Doc.A/C.1/PV 1289 (3 December 1962) at 13.
} 
On the other hand, at about the same time, Judge MANFRED LACHS had said:

\begin{abstract}
"The issue still remains subject to serious controversy. Yet there seems to be little doubt as to the real meaning of these words.

If it was intended to forbid aggressive uses only, mere reference to international law and the Charter of the United Nations would have sufficed. Is it not evident that they prohibit such action in all environments and outer space can be no exception? . . . 'Peaceful' cannot be limited to 'non-aggressive', it excludes what may be called 'military' uses. This remains true even if one takes into account the fact that not all military actions are necessarily 'nonpeaceful'. (Some may even be undertaken in order to maintain or restore international peace and security).

For the essential consideration is to prevent the extension of national rivalries into outer space, to arrest the dangerous developments in the global armaments race. Hence, the well justified claim for a special status of outer space: its use for non-military peaceful purposes only. This remains the goal."16
\end{abstract}

It does not seem that the lex specialis of the 1967 and other space-related treaties has made any fundamental departure from the basic legal position, even though it is generally believed that, as a result of the 1967 treaty, it is only the regime of the moon and other celestial bodies that has been totally demilitarised, while outer space per se has only been partially demilitarised.

As Professor M. MARCOFF points out, ${ }^{17}$ a partial demilitarisation does not imply that a given kind of space activity which has not been formally forbidden, is in accordance with international law of outer space. This is because the criteria of legality in matters of space law which is specified not only by the rules of prohibition in Art. IV of the 1967 treaty and other international law provisions, but also in the key provision of Art. 1(1) of the 1967 treaty: exploration and use of outer space shall be carried out for the benefit and in the interests of all countries, irrespective of their degree of economic or scientific development and shall be the province of all mankind. Military activities that are still not prohibited are just tolerated, but they remain in conflict with the basic norm of Art. 1(1) because no military activity of space nature, even if non-aggressive, might meet the requirement of that rule. Contemporary practice of using military devices cannot neutralise the 'general interests' rule, because they are carried out for the benefit of one State or a group of States, and not all countries. There is only one exception: the acceptance of an International Satellite Monitoring Agency (ISMA) proposed

\footnotetext{
${ }^{16}$ LACHS, loc.cit. n. 13 at $90-91$.

${ }^{17}$ Reply to questions put by the Chairman of the ILA Space Law Committee, in: International Law Association, Report of the Sixty-first Conference held at Paris (1984) 360-361.
} 
by France in 1978. Such an agency might fulfil the condition of Art. 1(1) in the matter of 'verification', or remote sensing space objects passing over foreign countries. There is no formal reservation to Art. 1(1) by any party although, as of 1991,90 States are parties to the treaty. This is particularly relevant because, as GoEDHUIS points out:

"[ . . ] notwithstanding the fact that more than half of the American and Soviet satellites registered so far, serve military purposes, not one of the launchings has been described as having a military function. Both the US and the Soviet Union pretend that all their satellites are "peaceful'."

It is common knowledge that satellites operating in outer space have both military and non-military functions and objects. There are satellites, intended for civilian purposes, but used to perform military functions. For example, reconnaissance satellites can be used both for the discovery of the origin of typhoons as well as for monitoring naval and troop movements, as was done during the Falkland War. The technique is neutral but its deployment depends upon the policy decision of a space power. The lack of publicity of the military character of satellite systems creates serious difficulties. It is estimated that some 75 per cent of all satellites are launched for military purposes; and it should be noted that 'all types of satellites essentially can have a military aspect: meteorological satellites; direct broadcasting satellites, remote sensing satellites; oceanographic satellites; geodetic satellites etc. ${ }^{19}$

Professor G.P. ZHUKOV challenges the United States interpretation (peaceful $=$ non-aggressive) and points out that those who support the view rely upon the impossibility of complete banning of military activities in outer space, one of the basic arguments being put forward is the reference to the fact that the majority of civilian space objects can also be used for military ends (dual-purpose space objects). Professor ZHUKOV comments:

\footnotetext{
"This is true, but it drives one to the conclusion that in the name of human progress it is necessary to put under a ban the use of such dual-purpose objects for military purposes and not [. . .] [to the conclusion of] the impossibility to ban military activity in the Space." 20
}

\footnotetext{
${ }^{18}$ Report of the ILA Space Law Committee, in: International Law Association, Report of the Sixtieth Conference held at Montreal (1982) 498.

${ }^{19}$ M. BENKö, W. DE GRAAFF and G.C.M. REINEN (eds.), Space Law in the United Nations (1985) 151; see also Subrata RoY CHOWDHURY, 'Legal Aspects of Maintaining Outer Space for Peaceful Purposes', Proceedings of the 31st Colloquium on the Law of Outer Space (Bangalore) 1988 at 13.

${ }^{20}$ Loc.cit. n. 18 at 502.
} 
The expansion 'exclusively for peaceful purposes' in the 1967 treaty appears only in relation to a regime for the moon and other celestial bodies. As a matter of interpretation, it would be meaningless if not absurd to substitute in the treaty that the moon and other celestial bodies should be 'exclusively for non-aggressive purposes'. It would be more consistent to read instead that the moon and other celestial bodies should be used 'exclusively for non-military purposes', barring stipulated exceptions permitting the use of military personnel or equipment for scientific research or other peaceful purposes. Again, the substitution of 'non-aggressive' for 'peaceful' purposes would be redundant because of the express incorporation of international law and the Charter of the United Nations in Art. III of the 1967 treaty and Art. 2 of the Agreement Governing the Activities of States on the Moon and other Celestial Bodies, 1979, and accordingly aggressive acts in outer space as a whole are forbidden.

Just as the test of legality in Art. 1(1) of the 1967 treaty has been declared to be the central theme of peaceful uses of outer space, professor I.H.PH. DIEDERIKS-VERSCHOOR considers Art. III of the 1967 treaty to be the 'cornerstone' of space law. It declares that States shall carry on activities in the exploration and use of outer space in accordance with international law including the Charter of the United Nations, in the interest of maintaining international peace and security. Professor DIEDERIKS-VERSCHOOR has added two other recent dimensions to the concept of peaceful use of outer space: first, environmental consequences of weapons in space have shifted the emphasis from purely military consideration; second, the growing utility of commercial use of space activity has given a new direction to the principle of peaceful purposes. ${ }^{21}$

The incorporation of the United Nations Charter in the international law of outer space focuses the relevance of two important resolutions of the General Assembly: resolution 2625 (XXV) of 24 october 1970 (Declaration on Principles of International Law Concerning Friendly Relations and Cooperation among States in Accordance with the Charter of the United Nations) and resolution 3314 (XXIX) of 14 December 1974 (Definition of Aggression). ${ }^{22}$

There are two aspects of the 1970 Declaration which are relevant in the present context: first, it recalls that outer space is not subject to national appropriation in any form, thereby underscoring its peaceful use for common

${ }^{21}$ I.H.PH. DIEDERIKS-VERSCHOOR, An Introduction to Space Law (1993) 125-128.

${ }^{22}$ Text of res. 2625 (XXV) in 9 ILM (1970) 1292; text of res. 3314 (XXIX) in 69 AJIL (1975) 480. 
benefit. In other words, as the late Judge NAGENDRA SINGH has explained, ${ }^{23}$ it reflects the shared anxiety of mankind for the right of present and future generations to protection, in their interest, of the res communis humanitatis (common heritage of mankind), a relatively new concept which has succeeded terra nullius. Second, the prohibition is not confined to a war of aggression (a crime against the peace) but expressly extends to acts of reprisal involving the use of force; such reprisal or retaliation being inconsistent with the purposes of the United Nations to maintain international peace. Again, apart from the permissible use of force in self-defense in case of actual 'armed attack', the dispute-resolving mechanism of the UN Security Council must be used. This excludes any unilateral use of force outside the collective security system of the United Nations. There is a further obligation to negotiate for the early conclusion of any international treaty on general and complete disarmament applicable equally to terrestrial and outer space regions. This means that since the Cold War is now a thing of the past, the rationale behind military alliances like the Atlantic Pact and the Warsaw Pact no longer exists and one has to turn to a regime of collective security both for preventive and enforcement action as stipulated in Chapter VII of the Charter.

It has been suggested that the definition of 'aggression' in the UNGA resolution 3314 (XXIX) applies mutatis mutandis to international space law. The first use of armed force in contravention of the Charter is prima facie evidence of an act of aggression unless the Security Council decides otherwise (Art. 2). That apart, what is relevant is Art. 3 which states that the following acts, inter alia, qualify as acts of aggression:

(a) The invasion or attack by the armed force of a State of the territory of another State; and

(b) Bombardment by the armed forces of a State against the territory of another State or the use of any weapons by a State against the territory of another State.

It is significant that the Explanatory Notes in the Report of the Special Committee on the question of defining aggression agreed that, with reference to Art. 3(b), the expression 'any weapons' is used without making any distinction between conventional weapons, weapons of mass destruction and any other kind of weapons. ${ }^{24}$ In view of this definition it is clear that in outer

\footnotetext{
${ }^{23}$ Judge Nagendra Singh, Foreword to R.D. Munro et al., Environmental Protection and Sustainable Development: Legal Principles and Recommendations (1986) at xix.

${ }^{24} 69$ AJIL (1975) 483.
} 
space per se there can be an act of aggression even though the weapons used are not nuclear weapons or any other kind of weapons of mass destruction.

Dr. GYULA GAL has analyzed the UN definition and stated that acts of aggression might include:

(1) Invasion or attack by the armed forces of a state on the territory of another state;

(2) Bombardment or the use of weapons against the territory of another state;

(3) The attack by the armed forces of a state on land, at sea or in the air against the land forces, sea or air fleets of another state.

Dr. GAL concluded:

\begin{abstract}
"Applying single elements of this definition to military space activity, an act of 'space aggression' in all three respects would be technically possible. Such act may be simply an attack on the territory of another state, an attack on armed forces of another state from outer space or a par excellence space attack, i.e., destroying a space object of another state by its own space object or ground or air-based ASAT weapon would also be an 'act of space aggression'.

The incorporation of the Charter into the body of space law by Article III of the Space Treaty makes it clear that an attack carried out by new-type weapons could also qualify as an act of aggression." 25
\end{abstract}

The meaning of the expression 'weapons of mass destruction' is far from clear. The expression has been described by one author as a typical misnomer on two counts: the weapons so indicated cannot 'destroy mass', and to the extent that the term aims to point to the massive or widespread destruction the weapons are supposed to cause, "there is not really all that much difference between the effects of the smaller versions of these weapons and the effects of certain modern so-called conventional seasons". ${ }^{26}$ This was considered in the Conference on Disarmament and it appeared that States have certain understanding that the expression includes chemical, biological and radioactive weapons, and as one US negotiator pointed out:

"[ . . ] and then being open-ended [ . . ] in order to take care of developments which one cannot specify at the present time, some form of weapon which

\footnotetext{
${ }^{25}$ GYULA GAL, "Threat or Use of Force", Observations on Article 2 of the U.N. Charter and Article III of the Outer Space Treaty', 17 Journal of Space Law (1989) 54-61 at 60.

${ }^{26}$ FrITS KALSHOVEN, 'Arms, Armaments and International Law', 191 Recueil des Cours (1985II) at 266.
} 
might be invented or developed in the future, which would have devastating effects comparable to those of nuclear or chemical or biological weapons but which one cannot simply describe at the present time."27

A recent example of a new weapon system which can be described as a mass destruction weapon can be seen in the non-nuclear precision-guided munitions used in the recent Gulf War. In December 1990, the Soviet General of the Army I.M. TRET'YAK, Air Defense Forces' Commander-in-Chief, in a press interview focused on this issue:

"The growth in power and accuracy of conventional weapons has brought them closer in effectiveness to tactical nuclear weapons, which permits planning their employment for strikes against strategic nuclear force targets and the state and military command and control system. Thus the accelerated development of conventional weapons and air assets for delivering them to strike targets not only does not reduce military danger, but even aggravates it to a certain extent." ${ }^{28}$

TRET'YAK also stated that:

"the United States and its NATO allies continue to strive for a military superiority over the USSR [ . . . ] the United States essentially has not cut back a single programme for creating new offensive airspace weapons and modernising existing ones." 29

Consequently, instead of substantially reducing air defense TRET'YAK asserted that the Soviet Union's air defense needed to be maintained and improved "to prevent an enemy from gaining air superiority and seize the initiative using SAMs and interceptor aircrafts". ${ }^{30}$

One would wish a fundamental change of attitude in regard to the current negotiations for prevention of an arms race in outer space similar in spirit to the recent developments for a global convention banning chemical weapons. In May 1991 the United States announced its intention to unconditionally destroy its chemical weapons stocks and the production of such weapons and to formally foreswear the use of chemical weapons under any circumstances,

\footnotetext{
2774 AJIL (1980) at 821 , note 82.

${ }^{28}$ General of the Army IVAN M. TRET'YAK, interview with Colonel V.P. CHIGAK, editor of the General Staff journal Voyennaya mysl, 'Defense Sufficiency and Air Defense', 12 Voyenna mysl (December 1990) 2.

${ }^{29}$ Ibid. See also Vlahos, DeAn and BERKowitz, loc.cit. n. 10 at 435-438.

${ }^{30}$ Ibid. at 435.
} 
including retaliation in kind against any State as of the Convention's entry into force. ${ }^{31}$

\section{EQUATION BETWEEN OFFENSIVE AND DEFENSIVE WEAPONS: ABM TREATY, SDI AND ASATS}

Any exercise for disarmament in outer space is critically linked with the broader question of disarmament in general. As then Senator GORE had correctly pointed out in 1962:

"The question of military activities in space cannot be divorced from the
question of military activities on earth. To banish these activities, we must
continue our efforts for general and complete disarmament with adequate
safeguards."32

The reduction of strategic offensive arms, limitations of anti-ballistic missile systems, and a moratorium followed by ultimate banning of antisatellite (ASATs) weapon systems are of vital importance in this regard.

It would be pertinent to refer briefly to the SDI/ABM treaty equation. It had been the consistent position of the REAGAN Administration that the Strategic Defense Initiative (SDI) (popularly known as Star Wars) would be in compliance with Anti-Ballistic Missile (ABM) Treaty of 1972 between the US and the USSR. President REAGAN was ecstatic about a new defensive spacebased, non-nuclear, strategic defense initiative for his concept of world-wide security. Such a system would enable the United States to intercept and destroy strategic ballistic missiles of the Soviet Union before they could reach the American soil.

On the other hand, the Soviet Union considered that by whatever name called, SDI was an offensive system to support American stations in orbit over the Soviet Union which would constitute a 'Sword of Damocles'. In response to the American proposal that the ABM treaty should be observed for a period of ten years during which SDI laboratory research would continue, Mr. SHEVARDNADZE was very critical of any prospect for future legalization of the advanced space-based defense and he retorted: 'We were invited to endorse the

\footnotetext{
${ }^{31}$ Yearbook of the United Nations 1991 at 50.

${ }^{32}$ Senator GORE, loc.cit. n. 15.
} 
development of space weapons and sign the treaty's (ABM) death sentence, postponing its execution for ten years'..$^{33}$

The linkage between strategic arms reduction and limitation of ballistic missile defense will clearly appear from the two pre ambular paragraphs to the $\mathrm{ABM}$ treaty which are important guideposts for the interpretation of the treaty provisions:

"Considering that effective measures to limit anti-ballistic missile systems
would be a substantial factor in curbing the race in strategic offensive arms
and would lead to a decrease in the risk of outbreak of war involving nuclear
weapons. Proceeding from the premise that the limitation of anti-ballistic
missile systems as well ascertain agreed measures with reference to the limit-
ation of strategic offensive arms, would contribute to the creation of more
favourable conditions of further negotiations on limiting strategic arms
[. . . ]"34

Articles III and V(1) and Agreed Statement ' $D$ ' are the important provisions of the treaty. Art. III contains the permissive provision for the deployment of only one fixed land-based ABM system (having a radius of $150 \mathrm{kms}$ ) and centred on the national capital of the party. Art. V(1) contains an undertaking not to develop, test or deploy ABM systems or components which are sea-based, air-based, space-based or mobile land-based. The Agreed Statement ' $D$ ' then provides:

\footnotetext{
"In order to ensure the fulfilment of the obligation not to deploy ABM systems and their components except as provided for in Article III of the Treaty, the Parties agree that in the event $A B M$ systems based on other physical principles and including components capable of substituting for ABM interceptor missiles, ABM launchers, or $\mathrm{ABM}$ radars are created in the future, specific limitations on such systems and their components would be subject to discussion in accordance with Art. XIII and agreement in accordance with Art. XIV of the Treaty."
}

The treaty is of unlimited duration but each party may withdraw by giving six months' notice "if it decides that extra-ordinary events related to the subject matter of this treaty have jeopardized its supreme interest" (Art. XV).

In the view of the REAGAN Administration, Agreed Statement ' $D$ ' on exotic technologies is to be read in conjunction with and as an expansion of

\footnotetext{
${ }^{33}$ L.A. Times, 6 November 1986, Part-1 at 8, col. 5-6. See also ChOWdHURY, loc.cit. n. 19 at 15.

${ }^{34}$ For text of the ABM Treaty, see BENKö, DE GRAAFF and REUNEN (eds.), op. cit. n. 19 at $188-$ 299.
} 
Article $\mathrm{V}$ of the treaty, not as a limitation on the basing modes and systems permitted under Art. III. However, critics say that ' $D$ ' only allows development and testing of new technologies that are introduced to replace fixed, landbased ABM systems or their substitutes. KEVIN KENNEDY pointed out that the views of the Administration differed substantially from the consenting Senate's understanding of the treaty, and a fair reading of Arts. III \& V(1) and ' $D$ ' read together suggested two conclusions: (a) the development and testing of 'Star Wars' technology in any basing mode other than a fixed, land-based mode is prohibited; and (b) deployment of such technology in even the fixed land-based mode is prohibited. ${ }^{35}$

JAMES P. RUBIN had observed that the ABM treaty was signed with the express purpose of making reductions in offensive arms possible. Without confidence that its offensive deterrent would remain effective, neither side would risk cuts in offensive forces; and ensuring this confidence requires not only a ban on deployment of defenses but also prohibitions against development and testing. With only a deployment ban, one country could begin constructing a defense and then break out to deploy the defense before the other side could respond by increasing its offensive system. For this reason, the liberal re-interpretation of the treaty by the Administration, which would permit unfettered development and testing of SDI in space, would be inconsistent with the underlying logic of strategic arms control. Hence adherence to the ABM treaty would remain critical to US security and a prerequisite to cuts in strategic arms. ${ }^{36}$

SDI conflicts remained unchanged although the original dome-like Star Wars was down-sized and finally, under president BUSH, SDI was further redrawn to provide ground and space defenses against limited ballistic missile attacks or accidental launches (Global Protection Against Limited Strikes or GPALs). ${ }^{37}$

As DUNBAR LOCKWOOD points out, ${ }^{38}$ while Russia is clearly interested in collaborating on a joint early warning system, in developing anti-tactical ballistic missiles (ATBMs) and, in receiving western technology and research

\footnotetext{
${ }^{35}$ KeVIN Kennedy, 'Treaty Interpretation by the Executive Branch: The ABM Treaty and "Star Wars" Testing and Development', 80 AJIL (1986) 854 at 862, 866.

${ }^{36}$ JAMES P. RUBIN, 'START Finish', Foreign Policy, Fall 1989, 96-118 at 111-114.

${ }^{37}$ MARCo RIMANELli, 'The Rationale, Evolution and Future of Arms Control', 11 Comparative Strategy (1992), 307-329 at 319.

${ }^{38}$ DUNBAR LOCKWOOD, 'START II, The penchant for peace', The Bulletin of the Atomic Scientists, October 1992 at 11.
} 
funds, it has never embraced space-based weapons. In an interview in June, 1992, Secretary of State JAMES BAKER said: "If we had said (to Russia), we're walking away from the ABM treaty just pure and simple [. . . ] I don't think we would have gotten this (START II) arms reduction agreement".

The position has not changed in post-Soviet Russia as would appear from a press interview to Izvestia by the Defence Minister of Russia PAVEL GRACHEV, published on June 23, 1992: "the process of strategic offensive arms cuts is tied in to observance of the ABM treaty. If the United States tries to step outside the bounds of this treaty the (START I and START II) accords will immediately lapse". ${ }^{39}$

On 28 January 1992 President YELTSIN announced a new set of proposals to attain 'minimal nuclear and conventional defence sufficiency'. The proposals include, inter alia:

i) that all new and existing strategic weapons modernisation and production be terminated (bombers and air and sea-launched cruise missiles);

ii) a bilateral halt to nuclear testings and the creation of an international agency for nuclear arms reduction and global control over the entire nuclear cycle from uranium mining to radioactive waste disposal;

iii) a sharp reduction in the military budget;

iv) adherence to the ABM treaty, elimination of reciprocal ASATs and cooperation with the United States in developing GPALs space-based defence. ${ }^{40}$

Several delegations at the Conference on Disarmament in 1992 expressed serious concern about the issue of GPALs. China, for instance, indicated that although the world had undergone major changes, the research and development of space weapons had not come to an end. In its view, the new antiballistic missile system was not totally defensive in nature and also had an attacking capability and hence the development of such a system would inevitably give rise to mutual suspicion among the States and contribute to more tensions in the world. It could also provoke countries with the ability to develop $A B M$ systems to speed up such eventuality. China stated that the implementation of GPALs would surely violate the ABM treaty which would

\footnotetext{
${ }^{39}$ Ibid. 45.

${ }^{40}$ Rimanelli, loc.cit. n. 37 at 324-325.
} 
either have to be terminated or amended ${ }^{41}$ In this context, it seems that if the assessment of the CIA Director WILLIAM WEBSTER at the 1989 Congressional hearing on nuclear and missile proliferation is correct, fifteen Third World countries would possess ballistic missiles by the year $2000 ;{ }^{42}$ these countries might be provoked to accomplish the programme with greater urgency.

The policy of the CLINTON Administration, when further clarified, would require a thorough evaluation. On 14 May 1993, US Defense Secretary ASPIN announced a new name and focus for the Strategic Defense Initiative Office (SDIO) to reflect priorities of the CLINTON Administration in the post-Cold War World. While allegedly ending the Star Wars era of strategic defence, an attempt is now being made to replace it with a refined ballistic missile defence. According to ASPIN, this is necessary to cope with the new danger of a postCold War, post-Soviet world. The SDIO will be replaced by the new BMDO (Ballistic Missile Defense Organization) and in this context, ballistic missile defence will be the first priority of the United States, consisting of theatre ballistic defense as well as national missile defense systems. ${ }^{43}$ Keeping in view the prohibitions and restrictions of the $A B M$ treaty and other arms control accords, one has to examine the ballistic missile defence programme of the CLINTON Administration when it is further clarified.

We now turn to the implications of the anti-satellite weapons systems (ASATs). Although ASATs have been described by some jurists as double purpose weapons, since they are designed not only for space warfare but also for ballistic missile defense, others have felt that because of their highly destabilising effects such weapons can hardly be described as defensive weapons. As early as 1983, the Council for the Federation of American Scientists described ASAT as a first-strike weapon, emphasized its impact in reducing strategic stability, urging the need for an immediate moratorium on testing to be followed by a limitation treaty. ${ }^{44}$

It is also said that future anti-satellite weapons would reduce strategic stability and their continued development would encourage renewed antiballistic missile competition. This was confirmed in a study by the American

\footnotetext{
41 Vladimir Bogomolov, 'Prevention of an Arms Race in Outer Space: Developments in the Conference on Disarmament in 1992', 20 Journal of Space Law (1992), 137-141 at 138.

${ }^{42}$ RimanELli, loc.cit. n. 37 at 322.

${ }^{43}$ See United States Information Service, Calcutta, 'Aspin Announces New Name and Focus for SDIO' (May 14, 1993).

${ }^{44}$ FAS Public Interest Report, 'Space Weapons Race - Stop it Now', 36 Journal of the Federation of American Scientists No. 9 (November 1983) at 1.
} 
Congressional Office of Technology which focused on the danger that the future ASAT technology might affect the very survivability of future satellites:

\begin{abstract}
"Nuclear weapons now being deployed or tested by the US and the Soviet Union are limited in altitude capability and responsiveness and can only attack a limited number of military satellites. Technologies applicable to future ASAT weapons would be able to attack virtually all military satellites of the type currently deployed. To maintain survivability of future satellites it will be necessary to constrain the development and deployment of ASAT weapons." 45
\end{abstract}

Dr. VLADIMIR KoPAL concluded:

\begin{abstract}
"Under these conditions, the negotiation and conclusion of a special agreement banning ASAT weapons remains one of the important goals which should be achieved as soon as possible. As an intermediate step, a moratorium on testing and developing such weapons should be agreed upon between the parties." 46
\end{abstract}

\title{
4. UN EXERCISE IN PREVENTING AN ARMS RACE IN OUTER SPACE
}

A convenient starting point would be paragraph 80 of the programme of action contained in the final document adopted at the tenth Special Session of the General Assembly in 1978 in the context of disarmament, which reads:

\footnotetext{
"In order to prevent an arms race into outer space, further measures should be taken and appropriate international negotiations held in accordance with the spirit of the Treaty (1967) [. . . ]"47
}

The UN General Assembly in its regular 36th session in 1981 discussed 20 disarmament items and adopted on 9 December 1981 a record number of 49 resolutions on specific disarmament questions. While Resolution 36/9 2D focused on the need for the conclusion of international agreements "keeping in mind the ultimate objective of general and complete disarmament under effective international supervision", Resolution 36/97C dealt specifically with the need for effective measures to prevent an arms race in outer space and

\footnotetext{
${ }^{45}$ Quoted by D. GoEdhuIs, Report of the ILA Space Law Committee, in: International Law Association, Report of the Sixty-third Conference held at Warsaw (1988) at 329.

${ }^{46}$ Ibid. 307-308.

${ }^{47}$ Yearbook of the United Nations 1978 at 44.
} 
requested the Committee on Disarmament from the very beginning of its 1982 session to consider "the question of negotiating effective and verifiable agreements aimed at preventing an arms race in outer space . . ." and further to consider as a priority measure the question of negotiating "an effective and verifiable agreement to prohibit anti-satellite systems" as an important step towards the fulfilment of the aforesaid objectives. ${ }^{48}$

The United Nations has been consistently perturbed by the increasing arms race in outer space and has been urging the international community to take preventive measures. This concern was expressed by the United Nations at various regular sessions, particularly the General Assembly's 36th (1981) to 47th sessions (1992), apart from the Second United Nations Conference on the Exploration and Peaceful Uses of Outer Space (UNISPACE 82). It was recognized that the introduction of weapons into the space environment and the deployment of new weapon systems would have a serious negative effect on the development of international cooperation for peaceful use and exploration and hence it was proposed by some delegations to the Committee on Peaceful uses of Outer Space (COPUOS) to include a new agenda item: "ensuring the use of outer space exclusively for peaceful purposes". Such discussions would lead to further elaboration of the principle of non-militarization of outer space as envisaged in Art. IV of the 1967 treaty. ${ }^{49} \mathrm{Dr}$. KoPAL highlights that a new basis for deliberations was created by the Soviet Draft Treaty on the Prohibition of the Use of Force in Outer Space and from Space against the Earth. Discussions followed at the 38th Session of the General Assembly (1983) on the Draft Treaty, resulting in the adoption of Resolution 38/70 of 15 December 1983 which, inter alia, emphasized that further effective measures to prevent an arms race in outer space should be adopted by the international community. As stated in the Conference on Disarmament (as the Geneva Committee on Disarmament came to be known from 1984) the international community has a primary role in negotiating an agreement or agreements for the prevention of an arms race in outer space. On the same day, in Resolution 38/90, the General Assembly called upon all States, particularly those with major space capabilities:

\footnotetext{
48 Yearbook of the United Nations 1981 at 19, 25, 82-83.

49 Dr. VladimIR Kopal, 'Evaluation of the Main Principles of Space Law in the Institutional Framework of the United Nations', 12 Journal of Space Law (1984-1985) 22-25, particularly at 23.
} 
"to undertake prompt negotiations, under the auspices of the United Nations, with a view to reaching agreement or agreements designed to halt the militarization of outer space and to prevent an arms race in outer space, thus contributing to the achievement of the internationally accepted goal of ensuring the use of outer space exclusively for peaceful purposes."

At the same time, the General Assembly also requested the COPUOS to consider as a matter of priority questions relating to the militarization of outer space, taking into account the need to coordinate the efforts of the COPUOS and the Conference on Disarmament. ${ }^{50}$

A survey of the pertinent resolutions of the General Assembly from 1981 to 1992 (both the pre-ambular and operative paragraphs) ) $^{51}$ basically reveal the following principles: First, since the exploration and use of outer space should be in the common interest of all mankind and for the benefit of all countries, such exploration and use "[s]hall be exclusively for peaceful purposes". Second, a constant reminder to the members of the United Nations that international law and the UN Charter mandate the duty to maintain international peace and to refrain from the threat or use of force - this is applicable to outer space. Third, the obligation under Art. III of the 1967 treaty should be followed both in letter and spirit. Fourth, grave concern was expressed at the danger posed to all mankind by an arms race in outer space, and in particular, "by the impending threat of the exacerbation of the current state of insecurity of developments that could further undermine international peace and security and retard the pursuit of general and complete disarmament" (Resolution 42/33 of 30 December 1987). Fifth, while welcoming bilateral initiatives between the two major space-powers, the goal always has been towards multilateral negotiations and agreements for preventing an arms race in outer space. In this regard the Conference on Disarmament has a primary role in negotiating such international agreements. Of particular relevance is the special study published in 1986 by the United Nations Institute for Disarmament Research (UNIDAR) on military activities in space, in the framework of international law, limiting its use for military purposes and prohibiting the use of force in outer space.

In 1991, the Conference on Disarmament considered the report of its Ad Hoc Committee on Outer Space, the work programme of which included examining and identifying issues relevant to the prevention of an arms race in

\footnotetext{
${ }^{50}$ Ibid. at 24.

${ }^{51}$ See, among others, resolutions 38/70 of 15 December 1983, 35/59 of 15 December 1985, 41/53 of 3 December 1986, 42/33 of 30 December 1987, 46/33 of 6 December 1991.
} 
outer space, existing agreements and proposals and future initiatives. Four new documents submitted under the item included those submitted by Canada concerning a paper on satellites harming other satellites and studies on overhead imaging for verification and peacekeeping. It is important to note that although a large number of members, mainly non-aligned countries, thought it desirable to undertake negotiations for a multilateral treaty immediately, the United States remained opposed to such a move. Two aspects which figured prominently in 1991 were anti-satellite (ASAT) systems and verification of an ASAT ban and confidence building measures. The Ad Hoc Committee in its conclusions noted that there had been continued general recognition of the importance and urgency of preventing an arms race in outer space and of the significant role that the legal regime in that area was playing and the need to consolidate and enhance its effectiveness. ${ }^{52}$

Some pertinent developments in the Conference on Disarmament in 1992 may also be noted in this context. China and some other delegations pointed out that while repeated reiteration of the need for confidence building measures in the area of preventing an arms race in outer space was helpful, yet it should not "obstruct the creation of a substantive and legally binding treaty banning all space weapons". That apart, many delegations indicated that in the postcold war period, preventing an arms race in outer space was one of the principal tasks facing the Conference on Disarmament. For this age of high technology and qualitative increases in weapons precision, outer space stood out as an environment vulnerable to militarization. They were of the view that the "weaponization of outer space was a political hazard to the space activities of mankind and the peaceful use of outer space. In their view it would be too late to set about once such weaponization became a fait accompli". ${ }^{53}$

Professor DIEDERIKS-VERSCHOOR rightly focused on the central issue of effective verification in regulating an arms control regime in outer space. Effective verification is absolutely essential to ensure compliance with any arms control treaty provisions and to assess the risk to the security of States arising from military activities. According to this distinguished Dutch jurist, verification is the key stumbling block on the road to a meaningful reduction of space-weaponry - a problem of great urgency.

The issue has been the subject of various comments in international legal circles. HE QIZHI (China) shares the opinion of many others in believing that

52 Yearbook of the United Nations 1991 at $65-67$.
${ }^{53}$ Bogomolov, loc.cit. n. 41 at 137-140. 
verification is an indispensable condition for achieving an arms control agreement. Analyzing the capabilities of both military and civilian satellites, he suggests that by using well-calibrated equipment on board of military satellites, more consistent and well defined data could be gathered, so that the discovery of violations is more certain and concealment of such action more difficult. He also points out that in view of the crucial role played by satellites, protection has been granted to them in international agreements, particularly in bilateral agreements between the USA and USSR. However, HE QUIZHI recommends an international verification regime to replace the currently familiar national technical means (NTM). Of particular relevance in this context is the proposal of France in 1978 for an International Satellite Monitoring Agency (ISMA). ${ }^{54}$ Although the French proposal could not be realised because the US thought the project too expensive, while the USSR gave no reaction, Professor DIEDERIKS points out an encouraging trend:

"Much later, in October 1990, during a session of the Special Committee on the Charter of the United Nations, the USSR has proposed the establishment of a UN verification authority to monitor compliance with the terms of arms control agreements and those aimed at reducing international tensions." 55

\section{CONCLUSION}

A regime of space without arms is based on the sound principle that, apart from interfering with the peaceful use of outer space by all countries, any development of new weapon systems for use in outer space will be highly vulnerable as they will constitute ideal targets in case of any future conflict, and can never serve to increase the security of the big powers. Hence the present developments disclose a disquieting and destabilising trend.

At a symposium held at McGill University, Professor DUPUY (France) appealed to the statesmen of the world to seize the golden opportunity of new dialogue and confidence-building between the two superpowers to encourage them to go beyond bilateralism and to make substantial progress in ensuring the peaceful use of outer space. ${ }^{56}$ I fully share the sentiment. This is the only

\footnotetext{
${ }^{34}$ DIEDERIKS-VERSCHOOR, op. cit. n. 21 at 129-130.

${ }^{55}$ Ibid. at 130.

${ }^{56}$ JOCHEN ERTER, 'Space Without Weapons', 17 Journal of Space Law (1989) 177-180.
} 
way to ensure a peaceful space regime without weapons, a goal the United Nations has been striving to achieve for three decades.

The only way to guarantee the survival of such a multilateral regime is to ensure international monitoring by appropriate United Nations agencies. This will also help to prevent the proliferation of outer space weapons technology and relieve the big powers from their current self-imposed burden of assuming what General GALLOIS had described as 'the role of a world gendarme'. ${ }^{57}$

${ }^{57}$ Ibid. 179. 